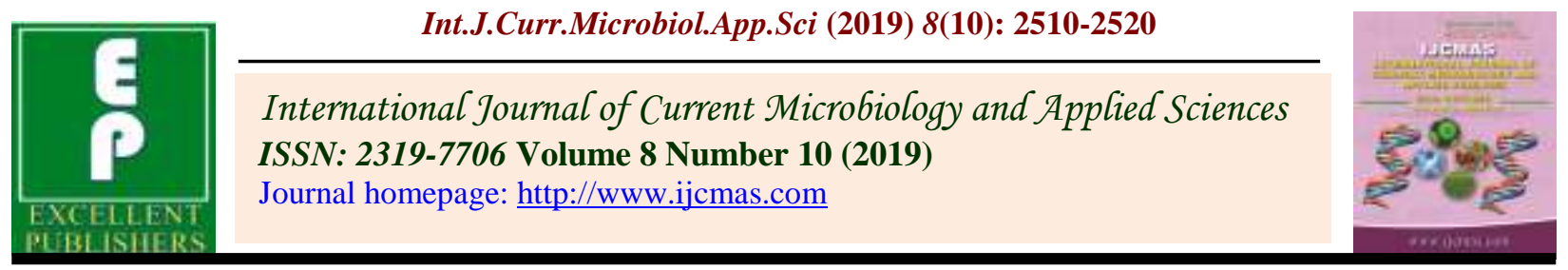

Original Research Article

https://doi.org/10.20546/ijcmas.2019.810.291

\title{
Polygenic Variations and Character Association in Early Maturing Indian Cauliflowers (Brassica oleracea var. botrytis L.)
}

\author{
Sangeeta Shree ${ }^{1}$, Randhir Kumar ${ }^{1}$, Nitish De $^{2}$ and Ravi Kumar ${ }^{1}$ \\ ${ }^{1}$ Department of Horticulture (Veg. and Flori.), ${ }^{2}$ Department of Plant Breeding and Genetics, \\ Bihar Agricultural University, Sabour - 813 210, Bhagalpur \\ *Corresponding author
}

Keywords

Genotypes, Quantitative parameters Analysis of variance, $\mathrm{GCV}$, PCV

Article Info

Accepted:

17 September 2019

Available Online:

10 October 2019

\section{A B S T R A C T}

Thirteen genotypes of early cauliflower were characterized for different quantitative parameters at the Vegetable Research Farm, at Bihar Agricultural University, Sabour during the Rabi season of 2010-2011 and 2011-2012. The experiment was laid out in a randomized complete block design with three replications. Pooled analysis of variance of the fifteen genotypes over two years indicated significant differences among the genotypes for all the characters under study. The range of variation was highest for marketable weight of curd followed by net weight of curd, days to $50 \%$ curd initiation, plant height, length of leaves and curd compactness. The traits such as net curd weight, curd compactness and marketable curd showed high PCV and GCV. High heritability along with moderate genetic advance were observed for marketable weight of curd, curd compactness, plant height and length of leaves which pointed towards the occurrence of additive gene action and hence phenotypic selection as such might be effective for improvement of these traits. Net weight of curd showed significant and positive genotypic and phenotypic correlation with plant height, length of leaves, width of leaves, diameter of curd, marketable weight of curd and curd compactness. Marketable weight of curd showed maximum direct positive contribution on net curd weight of curd at both genotypic and phenotypic level. The value for residual effect was found to be extremely low.

\section{Introduction}

Cauliflower (Brassica oleracea var. botrytis L.) is one of the important vegetable crops, grown throughout the year in different agroclimatic zones (Kaushal and Kaushal, 2013). It is mainly grown for its curds which are rich in vitamin-C (ascorbic acid) and also the minerals like phosphorus, potassium, calcium, sodium and iron. Also, cauliflower is low in fat, but high in dietary fiber. A high intake of cauliflower has been associated with reduced risk of aggressive prostate cancer (Kushwaha et al., 2013).

During the course of cultivation in India, cauliflower has undergone significant changes in its morphological characteristics and 
adaptability to warm and humid weather due to continuous selection and acclimatization. As a result, Indian cauliflowers today constitute a separate group both, morphologically and genetically from the temperate types (Swarup and Chatterjee, 1972). Agronomic traits such as curd yield and its components are major selection criteria for increasing its productivity (Yanglem and Tumbare, 2014). The morphological characters of a crop although subjected to variation through environmental influences, are undoubtedly the best indicators of yield and their correlation with yield. Therefore, they have received a great attention. The plant growth habit of the cultivars varies and exhibits a wide variation, which are unique and distinct. These morphological traits are useful in varietal identification and genetic purity testing. The data base of cauliflower genotypes generated by morphological characterization may be useful for the selection of suitable varieties developed in India as and when required.

Besides, crop improvement is based on available genetic variability and extent to which the desirable characters are heritable. Hence, studies on genetic variability with the help of suitable genetic parameters become indispensable for an effective breeding progamme. Yield is a very complex entity influenced by several yield components sensitive to the environmental fluctuations. Thus, the selection based on yield components will have better chance of success. It is therefore, necessary to know the types and nature of yield components and their inter relationship. The correlation coefficient analysis and path coefficient analysis provide information on the relative importance of various contributing characters. Measurement of existing variability in plant population has been the basic requirement of plant breeding.
Heritability and genetic advance have been proved useful in predicting the gain through selection. Therefore, the present investigation was carried out with the objectives of morphological characterization of cauliflower genotypes, estimates of genetic parameters of variation for different characters in cauliflower and inters relationship studies for yield and its contributing characters in cauliflower.

\section{Materials and Methods}

The experiment was conducted at Vegetable Research Farm, Department of Horticulture, at Bihar Agricultural College, Sabour, Bhagalur (Bihar) India during the Rabi season of 2010-2011 and 2011-2012. Experiment was laid out in a randomised complete block design with three replications. The sowing of all genotypes was done in nursery bed in the second fortnight of May and 23days old seedlings were transplanted at the spacing of $50 \mathrm{~cm}$ between rows and $40 \mathrm{~cm}$ between plants within the rows. Fifty plants were maintained in each genotype per replication. The package of practices to raise a successful crop of cauliflower was followed.

Collection and characterization of the existing variability is the first step to any breeding programme. In the present study, fifteen diverse genotypes of early cauliflower were characterized for different quantitative parameters. Morphological characterization has been done based on characters like plant height $(\mathrm{cm})$, number of leaves per plant, leaf length $(\mathrm{cm})$, width of leaf $(\mathrm{cm})$, days of curd initiation, days of curd maturity, average diameter of curd $(\mathrm{cm})$, curd compactness and average weight of curd. Observations were recorded on 05 randomly selected plants from each plot. Mean data were subjected to statistical analysis to calculate range, standard deviation and coefficient of variability. 


\section{Results and Discussion}

Pooled analysis of variance of the fifteen genotypes over two years indicated significant differences among the genotypes for all the characters under study. This points towards the existence of ample genetic variability worth exploiting in breeding program and was reflected in broad range value for different horticultural traits under study. The range of variation was highest for marketable weight of curd followed by net weight of curd, days to $50 \%$ curd initiation, plant height, length of leaves and curd compactness. Wide range of variability in cauliflower was also reported by Singh et al., (2006) for curd weight and net curd weight, Kumar et al., (2010) for days to $50 \%$ curd formation and net curd weight, Kumar et al., (2011) for days to 50\% curd formation, net curd weight and marketable curd yield, Chittora and Singh (2015) for total plant weight and net curd weight, Kumari et al., (2016) for total plant weight and marketable curd yield. For the characters studied, phenotypic variance was higher than genotypic variance (Table.1). High level of genotypic and phenotypic variances was noted for the marketable weight of curd, net weight of curd, days to $50 \%$ curd initiation and days to $50 \%$ curd maturity, while low level of genotypic and phenotypic variances observed for curd maturity duration, diameter of curd, width of leaf, plant height and number of leaves.

The absolute values genotypic and phenotypic variance are however of little importance for direct selection as there is no clear cut ceiling to these values to classify their variances as high or low. The coefficient of variation is an index for amount of potential variability present in the individual economic traits. It was also observed that PCV was slightly higher than the corresponding GCV for all the traits. This clearly indicated the presence of environmental influence to some degree affecting the expression of these characters. However the differences were narrow which implied their relative resistance to environmental variation (Roy Chowdhury and Tah, 2013). It also indicated that genetic factors were mainly accountable for expression of those traits and selection could be made effectively on the basis of phenotypic performance. Similar findings in cauliflower have been reported by Manaware et al., (2017), Dipti and Singh (2013), Kumar et al., (2011) and Singh et al., (2006). The traits such as net curd weight, curd compactness and marketable curd showed high PCV and GCV (Table 1). This result is in line with the conclusion of Santhosha et al., (2015) and in close harmony with findings of Manaware et al., (2017). The advancement of such characters can be brought about by subjecting the progenies to vigorous environmental condition. Characters like days to $50 \%$ of curd maturity, diameter of curd, width of leaf, length of leaf, plant height and number of leaves per plant exhibited low phenotypic and genotypic variation which is in consonance with results reported by Akshay and Singh (2015) and Sahu (2017).

It is not possible to estimate heritable variation with the help of genetic coefficient of variation (GCV) alone. However, GCV together with heritability estimate gives a better picture of the amount of advances to be expected by selection. In the present study, heritability was recorded high for most of the vital characters like marketable weight of curd, net weight of curd, curd compactness, curd maturity duration plant height and length of leaves while diameter of curd, days to $50 \%$ curd maturity and width of leaves recorded low heritability percentage.

Heritability estimates in broad sense alone does not give clear indication for selection of traits since significant environment interaction is noted (Johnson et al., 1955). 
Hence, heritability values considered along with the predicted genetic gain increase the effectiveness of this parameter as a tool in selection program. Genetic advance though an independent entity, has an added advantage over heritability where the characters is to be improved through segregating generations. In the present study, high heritability was observed for marketable weight of curd, net weight of curd, days to fifty per cent curd initiation, curd compactness, plant height and length of leaves. However, high heritability coupled with high genetic advance and genetic advance as percent of mean were observed in marketable weight of curd, net weight of curd and days to fifty per cent curd initiation which suggested the prevalence of additive gene action in the expression of these characters. Therefore selection based on the phenotypic performance of these characters would be useful for achieving the desired results. The results were in close conformity with the findings of Sahu (2017) Santhosha et al., (2015) and Singh et al., (2011) in cauliflower.

High heritability along with moderate genetic advance were observed for marketable weight of curd, curd compactness, plant height and length of leaves which pointed towards the occurrence of additive gene action and hence phenotypic selection as such might be effective for improvement of these traits. These results were in close proximity with the findings of Chittora and Singh (2015) and Chatterjee et al., (2018) in cauliflower. High heritability coupled with low genetic advance was observed curd maturity duration and number of leaves per plant. These findings were in agreement with the observations of Singh et al., (2011) in cabbage. This revealed the predominance of non-additive gene action in the expression of these characters; hence direct selection would not be effective and so, heterosis breeding could be exploited.
Correlation coefficient analysis assesses the shared relationship between plant characters and determines the component characters on which selection can be made for genetic improvement of yield. Investigation regarding the presence of component and nature of association among themselves is important and indispensable requirement for improvement in yield. Unfavourable association among the yield attributes under selection may result in genetic slippage (Dickerson, 1955). In the present study, correlation coefficient was worked out at phenotypic, genotypic and environmental levels for all possible combination of eleven yield and its attributing characters (Table 2). It was observed that the magnitude of genotypic correlation was higher than the phenotypic correlation for all the traits which point towards inherent association between various characters. The findings were in agreement to Rai et al., (2003), Rai and Asati (2004) and Meena et al., (2012). Net weight of curd showed significant and positive genotypic and phenotypic correlation with plant height $(\mathrm{cm})$, length of leaves $(\mathrm{cm})$, width of leaves $(\mathrm{cm})$, diameter of curd $(\mathrm{cm})$, marketable weight of curd (g) and curd compactness. Similar observations were also reported by Kumar et al., (2011), Santhosha et al., (2015), and Kumar et al., (2017) and Vanlalneihi1 et al., (2017) in cauliflower. However, negative but non-significant correlation was observed for curd maturity duration. Some characters do not indicate significant correlation with net curd yield which might be due to severe negative effects.

Correlation analysis illustrates the association among the characters but it does not give account of direct effect on the magnitude and nature towards yield. Path coefficient analysis facilitates the partitioning of correlation coefficients into direct and indirect effects of various characters on yield. 
Table.1 Estimates of genetic parameters of variations for different horticultural traits

\begin{tabular}{|c|c|c|c|c|c|c|c|c|c|c|c|}
\hline $\begin{array}{l}\text { Variations Parameters } \\
\downarrow\end{array}$ & $\begin{array}{l}\text { Plant } \\
\text { height } \\
\text { (cm) }\end{array}$ & $\begin{array}{l}\text { Number } \\
\text { of } \\
\text { leaves } \\
\text { per } \\
\text { plant }\end{array}$ & $\begin{array}{l}\text { Length } \\
\text { of } \\
\text { leaves } \\
(\mathrm{cm})\end{array}$ & $\begin{array}{l}\text { Width } \\
\text { of } \\
\text { leaves } \\
\text { (cm) }\end{array}$ & $\begin{array}{l}\text { Average } \\
\text { Diameter } \\
\text { of Curd } \\
\text { (cm) }\end{array}$ & $\begin{array}{l}\text { Days to } \\
50 \% \\
\text { Curd } \\
\text { initiation }\end{array}$ & $\begin{array}{l}\text { Days to } \\
50 \% \\
\text { Curd } \\
\text { maturity }\end{array}$ & $\begin{array}{l}\text { Curd } \\
\text { Maturity } \\
\text { Duration }\end{array}$ & $\begin{array}{l}\text { Marketable } \\
\text { weight of } \\
\text { curd (g) }\end{array}$ & $\begin{array}{l}\text { Net } \\
\text { weight } \\
\text { of curd } \\
\text { (g) }\end{array}$ & $\begin{array}{l}\text { Curd } \\
\text { compactness } \\
(\mathrm{g} / \mathrm{cm} 3)\end{array}$ \\
\hline Var Genotypical & 61.69 & 10.18 & 36.51 & 7.04 & 4.19 & 103.82 & 43.77 & 2.77 & 39483.98 & 35134.91 & 42.15 \\
\hline GCV & 15.01 & 14.37 & 13.82 & 11.76 & 15.05 & 17.13 & 8.50 & 27.20 & 44.36 & 59.31 & 49.67 \\
\hline Var Phenotypical & 75.93 & 16.16 & 45.54 & 12.56 & 8.23 & 126.66 & 85.37 & 3.62 & 40895.90 & 36733.03 & 51.62 \\
\hline PCV & 16.65 & 18.11 & 15.43 & 15.70 & 21.09 & 18.93 & 11.87 & 31.08 & 45.14 & 60.65 & 54.97 \\
\hline$h^{2}($ Broad Sense $)$ & 0.81 & 0.63 & 0.80 & 0.56 & 0.51 & 0.82 & 0.51 & 0.77 & 0.97 & 0.96 & 0.82 \\
\hline $\begin{array}{l}\text { Genetic Advancement } \\
5 \%\end{array}$ & 14.58 & 5.21 & 11.15 & 4.09 & 3.01 & 19.00 & 9.76 & 3.00 & 402.21 & 377.64 & 12.09 \\
\hline $\begin{array}{l}\text { Gen.Adv as \% of Mean } \\
5 \%\end{array}$ & 27.87 & 23.49 & 25.49 & 18.13 & 22.14 & 31.95 & 12.54 & 49.05 & 89.78 & 119.49 & 92.46 \\
\hline General Mean & 52.33 & 22.20 & 43.73 & 22.57 & 13.60 & 59.47 & 77.83 & 6.12 & 447.97 & 316.03 & 13.07 \\
\hline $\begin{array}{l}\text { Exp Mean next } \\
\text { Generation }\end{array}$ & 66.92 & 27.42 & 54.87 & 26.66 & 16.61 & 78.47 & 87.59 & 9.13 & 850.17 & 693.67 & 25.16 \\
\hline
\end{tabular}


Table.2 Estimates of genotypic and phenotypic correlation coefficients among Net Weight of Curd and its attributing traits

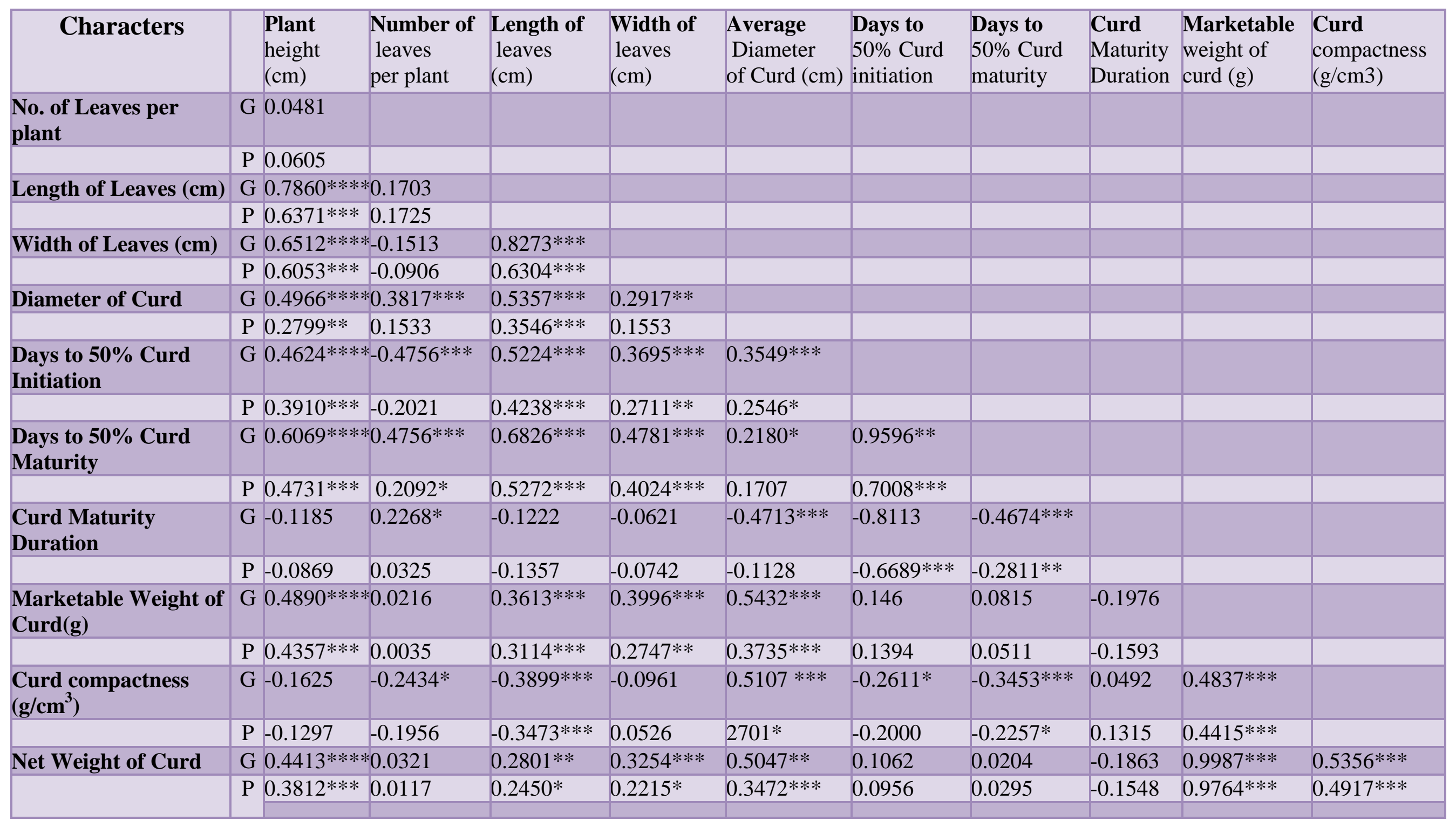


Table.3 Genotypic path coefficient showing direct and indirect effects of bulb yield and its contributing characters

\begin{tabular}{|c|c|c|c|c|c|c|c|c|c|c|}
\hline Characters & $\begin{array}{l}\text { Plant } \\
\text { height } \\
(\mathrm{cm})\end{array}$ & $\begin{array}{l}\text { Number } \\
\text { of } \\
\text { leaves } \\
\text { per plant }\end{array}$ & $\begin{array}{l}\text { Length } \\
\text { of } \\
\text { leaves } \\
(\mathrm{cm})\end{array}$ & $\begin{array}{l}\text { Width } \\
\text { of } \\
\text { leaves } \\
(\mathrm{cm})\end{array}$ & $\begin{array}{l}\text { Average } \\
\text { Diameter } \\
\text { of Curd } \\
(\mathrm{cm})\end{array}$ & $\begin{array}{l}\text { Days to } \\
50 \% \\
\text { Curd } \\
\text { initiation }\end{array}$ & $\begin{array}{l}\text { Days to } \\
50 \% \\
\text { Curd } \\
\text { maturity }\end{array}$ & $\begin{array}{l}\text { Curd } \\
\text { Maturity } \\
\text { Duration }\end{array}$ & $\begin{array}{l}\text { Marketable } \\
\text { weight of } \\
\text { curd (g) }\end{array}$ & $\begin{array}{l}\text { Curd } \\
\text { compactness } \\
(\mathrm{g} / \mathrm{cm} 3)\end{array}$ \\
\hline Plant Height (cm) & 0.0434 & 0.0021 & 0.0341 & 0.0282 & 0.0215 & 0.0201 & 0.0263 & -0.0051 & 0.0212 & -0.007 \\
\hline No. of Leaves per plant & -0.005 & -0.103 & -0.0175 & 0.0156 & -0.0393 & 0.0429 & 0.049 & -0.0234 & -0.0022 & 0.0251 \\
\hline Length of Leaves (cm) & 0.1575 & 0.0341 & 0.2004 & 0.1658 & 0.1074 & 0.1047 & 0.1368 & -0.0245 & 0.0724 & -0.0781 \\
\hline Width of Leaves (cm) & -0.1139 & 0.0265 & -0.1447 & -0.1749 & -0.051 & -0.0646 & -0.0836 & 0.0109 & -0.0699 & 0.0168 \\
\hline Diameter of Curd & 0.0141 & 0.0108 & 0.0152 & 0.0083 & 0.0283 & 0.0101 & 0.0062 & -0.0134 & 0.0154 & -0.0145 \\
\hline $\begin{array}{l}\text { Days to } 50 \% \text { Curd } \\
\text { Initiation }\end{array}$ & -0.1105 & 0.0994 & -0.1248 & -0.0883 & -0.0848 & -0.2389 & -0.2293 & 0.1938 & -0.0349 & 0.0624 \\
\hline $\begin{array}{l}\text { Days to } 50 \% \text { Curd } \\
\text { Maturity }\end{array}$ & 0.0026 & -0.0021 & 0.003 & 0.0021 & 0.0009 & 0.0041 & 0.0043 & -0.002 & 0.0004 & -0.0015 \\
\hline $\begin{array}{l}\text { Curd Maturity } \\
\text { Duration }\end{array}$ & 0.0172 & -0.0329 & 0.0177 & 0.009 & 0.0683 & 0.1176 & 0.0677 & -0.1449 & 0.0286 & -0.0071 \\
\hline $\begin{array}{l}\text { Marketable Weight of } \\
\text { Curd(g) }\end{array}$ & 0.451 & 0.0199 & 0.3332 & 0.3686 & 0.5011 & 0.1347 & 0.0752 & -0.1822 & 0.9225 & 0.4462 \\
\hline $\begin{array}{l}\text { Curd compactness } \\
(\mathrm{g} / \mathrm{cm} 3)\end{array}$ & -0.0152 & -0.0228 & -0.0364 & -0.009 & -0.0477 & -0.0244 & -0.0323 & 0.0046 & 0.0452 & 0.0935 \\
\hline Net Weight of Curd & 0.4413 & 0.0321 & 0.2801 & 0.3254 & 0.5047 & 0.1062 & 0.0204 & -0.1863 & 0.9987 & 0.5356 \\
\hline Partial R ${ }^{2}$ & 0.0191 & -0.0033 & 0.0561 & -0.0569 & 0.0143 & -0.0254 & 0.0001 & 0.027 & 0.9212 & 0.0501 \\
\hline
\end{tabular}


Table.4 Phenotypic path coefficient showing direct and indirect effects of net weight of curd and its contributing characters

\begin{tabular}{|c|c|c|c|c|c|c|c|c|c|c|}
\hline Characters & $\begin{array}{l}\text { Plant } \\
\text { height } \\
(\mathrm{cm})\end{array}$ & $\begin{array}{l}\text { Number } \\
\text { of } \\
\text { leaves } \\
\text { per plant }\end{array}$ & $\begin{array}{l}\text { Length } \\
\text { of } \\
\text { leaves } \\
(\mathrm{cm})\end{array}$ & $\begin{array}{l}\text { Width } \\
\text { of } \\
\text { leaves } \\
(\mathrm{cm})\end{array}$ & $\begin{array}{l}\text { Average } \\
\text { Diameter } \\
\text { of Curd } \\
(\mathrm{cm})\end{array}$ & $\begin{array}{l}\text { Days to } \\
50 \% \\
\text { Curd } \\
\text { initiation }\end{array}$ & $\begin{array}{l}\text { Days to } \\
50 \% \\
\text { Curd } \\
\text { maturity }\end{array}$ & $\begin{array}{l}\text { Curd } \\
\text { Maturity } \\
\text { Duration }\end{array}$ & $\begin{array}{l}\text { Marketable } \\
\text { weight of } \\
\text { curd }(\mathrm{g})\end{array}$ & $\begin{array}{l}\text { Curd } \\
\text { compactness } \\
(\mathrm{g} / \mathrm{cm} 3)\end{array}$ \\
\hline Plant Height (cm) & 0.0059 & 0.0004 & 0.0038 & 0.0036 & 0.0017 & 0.0023 & 0.0028 & -0.0005 & 0.0026 & -0.0008 \\
\hline No.of Leaves er plant & 0.001 & 0.0157 & 0.0027 & -0.0014 & 0.0024 & -0.0032 & -0.0033 & 0.0005 & 0.0001 & -0.0031 \\
\hline Length of Leaves (cm) & -0.01 & -0.0027 & -0.0158 & -0.0099 & -0.0056 & -0.0067 & -0.0083 & 0.0021 & -0.0049 & 0.0055 \\
\hline Width of Leaves (cm) & -0.021 & 0.0031 & -0.0218 & -0.0346 & -0.0054 & -0.0094 & -0.0139 & 0.0026 & -0.0095 & 0.0018 \\
\hline Diameter of Curd & 0.0099 & 0.0054 & 0.0126 & 0.0055 & 0.0355 & 0.009 & 0.0061 & -0.004 & 0.0133 & -0.0096 \\
\hline $\begin{array}{l}\text { Days to } 50 \% \text { Curd } \\
\text { Initiation }\end{array}$ & -0.042 & 0.0217 & -0.0455 & -0.0291 & -0.0274 & -0.1075 & -0.0753 & 0.0719 & -0.015 & 0.0215 \\
\hline $\begin{array}{l}\text { Days to } 50 \% \text { Curd } \\
\text { Maturity }\end{array}$ & 0.0352 & -0.0156 & 0.0392 & 0.0299 & 0.0127 & 0.0521 & 0.0744 & -0.0209 & 0.0038 & -0.0168 \\
\hline Curd Maturity Duration & 0.006 & -0.0022 & 0.0094 & 0.0051 & 0.0078 & 0.0462 & 0.0194 & -0.0691 & 0.011 & -0.0091 \\
\hline $\begin{array}{l}\text { Marketable Weight of } \\
\text { Curd(g) }\end{array}$ & 0.4078 & 0.0033 & 0.2914 & 0.2571 & 0.3495 & 0.1304 & 0.0478 & -0.1491 & 0.9358 & 0.4132 \\
\hline Curd compactness (g/cm3) & -0.0115 & -0.0174 & -0.0309 & -0.0047 & -0.0241 & -0.0178 & -0.0201 & 0.0117 & 0.0393 & 0.089 \\
\hline Net Weight of Curd & 0.3812 & 0.0117 & 0.245 & 0.2215 & 0.3472 & 0.0956 & 0.0295 & -0.1548 & 0.9764 & 0.4917 \\
\hline Partial $\mathbf{R}^{2}$ & 0.0023 & 0.0002 & -0.0039 & -0.0077 & 0.0123 & -0.0103 & 0.0022 & 0.0107 & 0.9137 & 0.0438 \\
\hline
\end{tabular}


In the present investigation path coefficient analysis study (Table.3 and Table.4) was done at phenotypic as well as genotypic level for characters under study using genotypic and phenotypic correlation coefficient and taking net weight of curd as dependable variable, so as to identify the direct and indirect effects of components affecting the net weight of curd. In the present study, almost similar trend was shown by both phenotypic and genotypic path coefficients. Genotypically, marketable weight of curd showed maximum direct positive contribution on net curd weight of curd and it was followed by length of leaves. At phenotypic level, marketable weight followed by curd compactness of curd had maximum direct positive contribution on net curd weight. This indicates that direct selection for marketable weight of curd and curd compactness would be very effective for net curd weight improvement. This is in conformity with the findings of Kumar et al., (2011), Sheemar et al., (2012), Nimkar (2013), Singh et al., (2013) and Santhosha et al., (2015). The negative direct effects were recorded for number of leaves per plant width of leaves, days to $50 \%$ curd initiation and curd maturity duration. More or less similar trends were observed at both genotypic and phenotypic level. Similar observations were recorded by Sahu (2017) for length of leaf and width of leaf and Singh et al., (2006) and Sheemar et al., (2012) for number of leaves per plant. At the genotypic level, diameter of curd followed by plant height, curd compactness, width of leaves and length of leaves exhibited major positive indirect effects on net curd weight. However, days to $50 \%$ curd maturity followed by curd maturity duration, showed maximum negative indirect effect on net curd weight. The value for residual effect was found to be extremely low which indicated the competency of the analysed characters in maximizing the curd yield and that there were very few other contributors which were responsible for net yield but not taken into consideration in the present investigation. According to Sengupta and Kataria (1971), this residual effect towards yield might be due to other characters (which were not studied), environmental factors and sampling errors.

Thus the present findings highlighted the existence of adequate genetic variability in the germplasm and the need to evaluate them for economic traits improvement. The traits that showed positive correlation with yield and also exhibited direct or indirect effect on yield could be exploited to bring improvement in yield and yield components.

\section{References}

Akshay, C. and Singh, D. K. 2015. Genetic variability studies in early cauliflower (Brassica oleracea var. botrytis L.). Electronic Journal of Plant Breeding. 6(3): 842-847.

Chatterjee, S., Aralikatti, O., Sharma, S., Mukherjee, D., Patil, S., Kanwar, H.S. and Choudhuri, P. 2018. Studies of Genetic Variability, Heritability and Genetic Gain for Some Important Horticultural Traits in Cauliflower (Brassica oleracea var. botrytis L.). Int.J.Curr.Microbiol.App.Sci. 7(04): 8292.

Chittora, A. and Singh, D.K. 2015. Genetic variability studies in early cauliflower (Brassica oleracea var. botrytis). Electronic Journal of Plant Breeding. 6(3): 842-847.

Dickerson, G. E. (1955). Stability analysis for yield and its components under different fertility regimes in French Bean. Vegetable Science., 26 (1): 6-11.

Diksha Manaware, A.K. Naidu and Narayan Lal. 2017. Genetic Diversity Assessment for Growth and Yield Traits in Cauliflower. Int.J.Curr.Microbiol. App.Sci. 6(8): 3016-3027. 
Dipti, M. and Singh, D. K. 2013. Studies on genetic variability for yield and its contributing attributes in early cauliflower (Brassica oleracea var. botrytis L.). Pantnagar Journal of Research. 11(2): 261-265.

Johnson, H. W., Robinson, H. F. and Comstock, R. E. 1955. Estimates of genetic environmental variability in soybeans. Agronomy journal. 47(7): 314-318.

Kaushal, M. and Kaushal, R. 2013. Plant growth promoting rhizobacteriaimpacts on cauliflower yield and soil health. The Bioscan. 8(1): 01-10

Kumar, M., Sharma, S.R., Kalia, P. and Saha, P. 2010. Genetic variability and character association for quantitative and quality traits in early maturing Indian cauliflowers. Indian Journal of Horticulture, 67: 218-223.

Kumar, M., Sharma, S.R., Kalia, P. and Saha, P. 2011. Genetic variability and character association for yield and quality traits in early maturing Indian cauliflowers. Indian Journal of Horticulture, 68(2), June 2011: 206-211

Kumar, V., Singh, D. K., Panchbhaiya, A. and Singh, N. 2017. Correlation and path coefficient analysis studies in midseason cauliflower (Brassica oleracea var. botrytis L.). Journal of Pharmacognosy and Phytochemistry. 6(4): 1130-1137.

Kumari, S., Katoch, V., Sharma, A. and Kumar, V. 2016. Variability studies in sprouting broccoli hybrids (brassica oleracea l. var. italica plenck) under mid hills of north western Himalayas. The Bioscan, 11(1): 569-572.

Kushwaha, A. Baily, S.B. Maxton, A. and Ram, G.D. 2013. Isolation and characterization of PGPR associated with cauliflower roots and its effect on plant growth, The Bioscan 8(1): 95-99

Manaware, D., Naidu, A. K. and Lal, N. 2017.
Genetic diversity assessment for growth and tield Traits in cauliflower. International Journal of Current Microbiology and. Applied Science. 6(8): 3016-3027.

Meena, M.L., Ram, R.B., Lata, R. and Sharma, S.R. 2012. Estimates of genetic variability and correlation studies for some quality traits in cabbage (Brassica oleracea var. capitata). Indian Journal of Agricultural Sciences, 82 (4): 370372.

Nimkar, S.A. 2013. Correlation and path coefficient studies in biparental progenies in cauliflower (Brassica oleracea var. botrytis L.). Research journal of Agricultural Science. 4(5/6): 667-669.

Nimkar, S.A. and Korla, B.N. 2011. Evaluation of biparental progenies developed through bud and mixed pollination for horticultural and quality traits in late cauliflower (Brassica oleracea var. botrytis L.). Indian Journal of Agricultural Research. 45(3): 215-20.

Rai, N., and Asati, B.S. 2004. Correlation and path coefficient analysis for the yield and its traits in cabbage. Orissa Journal of Horticulture, 32 (1): 48-51.

Rai, N., Singh, A.K. and Yadav, R.K. 2003. Correlation and path coefficient analysis for the yield and its traits in cabbage. Indian Journal of HillFarming, 16 (1/2):61-65.

Roy chowdhury, R. and Tah, J. 2013. Mutagenesis- A Potential Approach for Crop Improvement In: Crop Improvement (Eds.) Hakeem, K. R., Ahmed, P. And Oztark, M. Springer, New York. Pp. 149-188.

Sahu, P. K. 2017. Studies on genetic variability and self-incompatibility in Indian cauliflower (Brassica oleracea (L.) var. botrytis), M.S. Thesis, Indira Gandhi Krishi Vishwavidyalaya, India. 
Santhosha, H. M., Varalakshmi, B. And Manohar, R. K. 2015. Evaluation of early cauliflower (Brassica oleracea var. botrytis L.) germplasm under tropical conditions for various horticultural traits. The BioScan. 10(4): 1631-1635.

Sengupta K., Kataria A. S. 1971. PathCoefficient Analysis for some Characters in Soybean. Indian Journal of Genetics and Plant Breeding. 31(2), 290-295

Sheemar, G., Singh, D., Malik, A. and Kumar, A. 2012. Correlation and path analysis studies of economic traits in cauliflower (Brassica oleracea var botrytis L.). Journal of Agricultural Technology, 8(5): 1791-1799.

Singh, B., Mishra, A.K., Sanwal, S.K., Singh, P.K. and Rai, M. 2013. Genetic variability and character association analysis in cabbage hybrids. Indian Journal of Horticulture. 70(2): 296-299.

Singh, B., Pandey, A.K., Verma, A. and Rai, M. 2006. Genetic Variability in Aghani Group of Indian Cauliflower (Brassica oleracea var. botrytis). Indian Journal of Plant Genetic Resources, 19(1): 113117.

Singh, B.K., Sharma, S.R., Kalia, P. and Singh, B. 2011. Genetic variability for antioxidants and horticultural traits in cabbage. Indian Journal of Horticulture, 68 (1): 51-55

Swarup, V., and Chatterjee, S.S. 1972. Origin and genetic improvement of Indian cauliflower. Economic Botany, 26: 381393.

Vanlalneihi, B., Partha Saha and Mohita Srivastava. 2017. Assessment of Genetic Variability and Character Association for Yield and Its Contributing Components in Mid Maturing Indian Cauliflower. Int.J.Curr.Microbiol.App.Sci. $\quad$ 6(11): 2907-2913.

Yanglem, S.D. and Tumbare, A.D. 2014. Influence of irrigation regimes and fertigation levels on yield and physiological parameters in cauliflower. The Bioscan. 9(2): 589-594.

\section{How to cite this article:}

Sangeeta Shree, Randhir Kumar, Nitish De and Ravi Kumar. 2019. Polygenic Variations and Character association in Early Maturing Indian Cauliflowers (Brassica oleracea var. botrytis L.). Int.J.Curr.Microbiol.App.Sci. 8(10): 2510-2520. doi: https://doi.org/10.20546/ijcmas.2019.810.291 